\title{
The SWOT Analysis for the Development of Clove Plants (Syzygium Aromaticum) in Teupah Barat Sub-District, Simeulue District
}

\author{
Teuku Athaillah*, Raidayani, Ogin Sanjaya, Bagio \\ Study Program of Agribusiness, Faculty of Agriculture \\ Teuku Umar University \\ West Aceh, Indonesia \\ *athaillah.teuku@utu.ac.id
}

\begin{abstract}
The aim of this research is to determine the right strategies for the development of clove plants in Teupah Barat Sub-district, Simeulue District by using SWOT analysis Determining the right strategy for the development of clove plants in Teupah Barat Sub-district will make Teupah Barat Sub-district one of the largest clove-producing areas in Indonesia. The method used in this research is SWOT analysis where 2 factors will be obtained. The first factor is internal factors, namely Strengths and Weaknesses; the second one is external factors, consisting of Opportunities and Threats. The results showed that the right strategy for clove development in Teupah Barat Sub-district is by using the SO (StrengthOpportunities) strategy, which means creating a strategy by using strength to take advantage of existing opportunities including (1) Farmers must continue to expand their clove crop more than before (2). Farmers must replace damaged plants with new plants in order to increase production yields (3) The selection of quality clove seeds so that the yields obtained are of high quality (4) Farmers must form farmer groups in order to obtain information rapidly.
\end{abstract}

\section{Keywords—clove plants, SWOT analysis, Simeulue}

\section{INTRODUCTION}

Cloves as one of the leading commodities in the plantation sector are the native plants in Indonesia. Clove plants are widely grown throughout the archipelago. Quoting data from the Central Statistics Agency (BPS), the clove exports from Indonesia reached 54,91 million US dollars for the January July 2019 period, or in another word, an increase of 137,60\% from the same period last year which was 23,110 million US dollars. Previously, the export destination country was dominated by Saudi Arabia with a total of 797,8 tons. For the same period in 2019, the export destination country was dominated by India, which purchased up to 4,25 million tons of cloves worth the US \$15,8 million.

One of District cultivating clove plants in the Province of Aceh is Simeulue District. Simeulue District consists of ten Sub-districts such as Teupah Barat, Teupah Tengah, Teupah
Selatan, Simeulue Timur, Simeulue Tengah, Simeulue Barat, Simeulue Cut, Salang, Teluk Dalam, and Alafan sub-districts. Simeulue District is the suitable area for clove cultivation. According to data of the Simeulue District Plantation Office, Simeulue District produced cloves massively with a total production of 3.719 tons in 2019.

TABLE I. Clove Plants AREA IN SimeUlue District IN 2019

\begin{tabular}{|l|l|l|l|l|l|}
\hline No. & Sub-districts & $\begin{array}{c}\text { Total } \\
\text { Area } \\
(\mathbf{H a})\end{array}$ & $\begin{array}{c}\text { Production } \\
\text { (Ton) }\end{array}$ & $\begin{array}{c}\text { Average } \\
\text { Productivity } \\
(\mathbf{K g} / \mathbf{H a})\end{array}$ & $\begin{array}{c}\text { Farmers } \\
\text { (Family } \\
\text { Register) }\end{array}$ \\
\hline 1 & Teupah Barat & 5015 & 1456 & 640 & 1207 \\
\hline 2 & Salang & 887 & 433,8 & 600 & 1095 \\
\hline 3 & Simeulue Barat & 873 & 377 & 680 & 1012 \\
\hline 4 & Alafan & 710 & 335,42 & 620 & 1080 \\
\hline 5 & Teupah Selatan & 2657 & 303,18 & 620 & 1172 \\
\hline 6 & Teupah Tengah & 1612 & 259,84 & 580 & 1127 \\
\hline 7 & Teluk Dalam & 627 & 197,34 & 660 & 1022 \\
\hline 8 & Simeulue Tengah & 982 & 137,02 & 620 & 1260 \\
\hline 9 & Simeulue Cut & 962 & 116,58 & 580 & 1055 \\
\hline 10 & Simeulue Timur & 1635 & 102,5 & 580 & 1036 \\
\hline Total & & 15560 & 3719 & 618 & 11066 \\
\hline
\end{tabular}

Based on Table 1, it can be seen that the area owning the most extensive clove plants was Teupah Barat Sub-district. The total area of clove plantations in Teupah Barat Sub-district was 5015 hectares, where immature plants (TBM) with an area of 445 hectares, productive plants (TM) with an area of 2275 hectares, and damaged plants (TR) with a plant area of 2285 hectares. The area of damaged crops (TR) of cloves in Teupah Barat Sub-district was wider than immature plants (TBM) and mature plants (TM).

The total clove production in Teupah Barat Sub-district in 2019 was 1.456 tons with the average productivity in one hectare of clove plants was $640 \mathrm{~kg}$. Determining the right strategy for the development of clove plants in Teupah Barat Sub-district will make Teupah Barat Sub-district be one of the largest cloves producing areas in Indonesia. 
The purpose of this study is to determine the right strategy for the development of clove plants in Teupah Barat Subdistrict, Simeulue District by using SWOT analysis. The SWOT analysis is a process engaging four areas into two dimensions. It has four components such as: 'Strengths', 'weaknesses', 'opportunities', and 'threats'. Strengths and weaknesses are internal factors and organizational attributes, while opportunities and threats are external factors as well as environmental attributes [1].

Kajanus et al. used SWOT analysis to attain an orderly approach to decision-making [2]. Many researchers in different fields [3] apply SWOT analysis. An overview of the applications of SWOT analysis is given by Helms and Nixon [4]. SWOT analysis has been applied in the education domain by Dyson [5]. It has also been applied to healthcare, government and not-for-profit organizations, to handle countrylevel issues [6] and for sustainable investment-related decisions [7]. Thus, the SWOT Analysis is certainly can be used to find the right strategies for the clove development in Simeulue District.

\section{RESEARCH METHODS}

This research was conducted from January 2020 to April 2020 in Teupah Barat Subdistrict, Simeulue District; the determination of the location was conducted on purpose (Purposive Sampling) since the sub-district is the highest producer of cloves in Simeulue District. In determining the strengths, weaknesses, opportunities, and threats, in-depth interviews were carried out with parties from the Simeulue District Plantation Office, clove farmers, and related experts. After obtaining the factors of the strengths, weaknesses, opportunities, and threats, the IFAS and EFAS matrices were then calculated. The samples taken to determine the weight in the matrix were 36 families of clove farmers in Teupah Barat Subdistrict, Simeulue District. The results of the distributed questionnaires were then calculated by:

$$
\text { Weight }=\frac{\text { Obtained Value }}{\text { Total Value }}
$$

The rating was prescribed based on the results of in-depth interviews with the Simeulue District Plantation Office and experts. The result of the weight on each factor was then multiplied by the rating.

The method used in this research is SWOT analysis. External and internal factors are used to analyse more deeply concerning SWOT. The function of SWOT analysis is to get information from the situation analysis and separate it into internal issues (strengths and weaknesses) and external issues (opportunities and threats) [8]. SWOT is used to assess the strengths and weaknesses of the possessed resources. SWOT analysis can be used in a variety of ways to improve analysis in strategy-setting efforts [9].

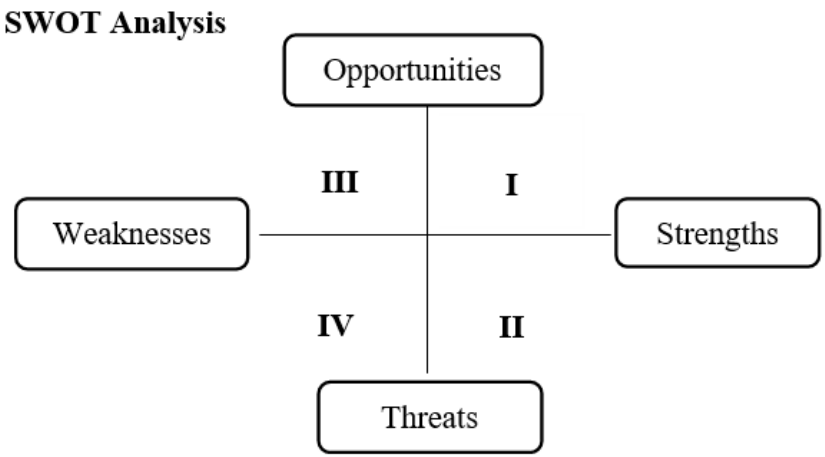

Fig. 1. SWOT analysis.

- Quadrant I: Shows a favourable situation because it has opportunities and strengths so it must be supported by aggressive growth policies in this position.

- Quadrant II: We have threats in this position, but there are still strengths from an internal perspective so the threats can be overcome with the existing strengths.

- Quadrant III: Shows that there are big opportunities but there are internal weaknesses as well, then the strategy taken must be precise so that the existing weaknesses do not reduce the size of the opportunities.

- Quadrant IV: This position is a very detrimental position since it has to face a variety of threats with weak internal conditions. The strategy applied must support the defensive strategy.

Thus, the matrix consists of four quadrants, where each quadrant contains each strategy. In the strategic planning process, there are three stages of analysis namely data collection stage, analysis stage, and decision-making stage. In the first stage, known as the data collection stage, an evaluation of internal and external factors is conducted to obtain the required data. The next stage is the analysis stage where there are several models of analysis tools such as the EFAS Matrix, IFAS Matrix, and SWOT Matrix [10]. EFAS is an analysis derived from the theory of SWOT analysis [11]. The last stage is the process of drafting strategy planning.

\section{RESULTS AND DISCUSSION}

Based on the interview results with several informants from the Plantation Office of Simeulue District and experts, it can be concluded that there are five main factors of strength and weakness from internal factors. While from external factors, there are also five factors of both opportunity and threat.

\section{A. Factors Including Strengths}

1) Owned land: Cloves in Teupah Barat Subdistrict are generally planted on their own land. In contrast to farmers in other places who grow cloves on leased land such as in other sub-districts in Simeulue District, this factor is the strength of 
farmers in Teupah Barat Sub-district. Cultivating in their own land made the yields received by farmers is even greater.

2) Land fertility: The fertility of clove land in Teupah Barat Subdistrict, Simeulue District, is quite fertile as can be seen from the largest clove production in Simeulue District. We can have a look at table 1, when compared to other subdistricts such as those are in Simeulue Timur Sub-district, the land is quite spacious but the production is very little.

This fertile land is one of the driving factors for farmers in developing cloves because plants grow faster with the fertile land than that of usually infertile.

3) Good plant growth: The growth of clove plants in Teupah Barat Sub-district is fairly good since it is rare for plants to die at the beginning of planting. The average plant growth is in accordance with the target, as the age of clove production fits the age of production in general between the ages of 4,5 to 5 years. Having good plant growth makes it easier for farmers in the development process. This is one of the farmers' strength factors in developing clove plants.

4) Farming business location: On average, the farmers' clove plantations are located quite close to their residences about $0.5-1 \mathrm{~km}$. Living near the plantation's location makes farmers easier to pay attention to their plants in case the clove plants are attacked by pests and diseases.

5) Empty land: Most of the farmers still have a lot of empty lands. Having a large number of empty land owned by farmers, they can still grow more cloves and on a wider scale.

\section{B. Factors Including Weaknesses}

1) Lack of knowledge: Some farmers in Teupah Barat Subdistrict still have no idea on how to handle pests and diseases in clove plants. When it occurs, they just let it happen and commit no certain handling. In contrast, it is different compared to other places such as farmers in Alafan Subdistrict having less damaged crops (TR) compared to other Sub-districts as shown in table 1, farmers in Alafan frequently visit and invite extension workers to get guidance to cope with the issue.

2) Lack of attention to plants: After the planting process, farmers rarely pay attention to their crops or take care of their plants again. Due to a lack of attention to plants, farmers rarely clean the garden area so that there are many other large trees growing around the clove plants. The nutrient elements of the farmers' clove plants are divided with trees other than the cloves. In addition, due to the large trees, clove plants do not grow optimally to get exposed to the sun and as a result, the trees become small and reduce harvest capacity.

3) Insufficient funds: Farmers in Teupah Barat Sub-district often experience insufficient funds in handling pests and diseases due to their limited funds in purchasing clove plants' medicines. Due to the lack of medicines, most of the clove plants are attacked by pests as bad as the lack of capital which also greatly affects the new land clearing process.

4) Poor quality seeds: Farmers use plenty of living seeds under clove trees as clove plant seeds. Naturally, old seeds fall down till they can live independently under the clove trees. Farmers then move the seeds to an empty place. Poor quality seeds cause some clove plants to grow more slowly.

These clove seeds are also very influential on the production of cloves themselves if they are in high-quality forms then they grow quickly and produce more. While most poor-quality seeds die during plantation and the resulting production are usually less than the high-quality ones.

5) Lack of fertilizer: Lack of fertilization in plants makes some plants unhealthy and does not grow well. Fertilizer deficiency factors also have an impact on the production of cloves themselves. The first impact is slow cloves produce production where the cloves are actually in the production age but are not producing. The second impact is many clove plants are not in the producing state.

\section{Factors Including Opportunities}

1) High price: The high price of cloves becomes one of the encouragements for farmers to continue planting cloves. The price of cloves ranges from Rp. 60.000-120.000/ kg. Even though the price has fallen to $\mathrm{Rp} 60.000 / \mathrm{kg}$, this price can still make farmers profit.

2) Large number of buyers: The highest clove production in Aceh Province resides in Simeulue District. The high clove production results attract many buyers not only from inside but also from outside of Simeulue Island. Having a large number of buyers, farmers greatly benefit especially in the marketing process since they do not need to find buyers to sell cloves and enable them to bid on the price of their cloves at a higher price.

3) Product quality: In terms of demand for clove products, buyers generally choose dry cloves. Dry cloves have a long shelf life and possess good quality compared to freshly dried cloves and for that reason, they are usually favored by the buyers because of the decent quality and have a higher bid. If at any time the price of cloves is getting low, farmers can store cloves in advance and wait for the price to get back normal. The good quality of clove flower products in Teupah Barat Sub-district will make cloves in Simeulue become the main clove in the manufacture of kretek cigarettes (unfiltered cigarettes) not only in Indonesia but also in other countries.

4) Technology and information development: The development of technology and information nowadays make farmers know the price level on the market easier. Farmers also find it easier to sell the product outside Simeulue District areas.

5) Product uniqueness: Cloves can be used as a mixture of kretek cigarettes. As cigarette sales are increasing every year, 
clove flowers can also be used as ingredients for medicine apart from cigarette mixture only.

\section{Factors Included in Threats}

1) Weather: Weather is a threat factor for clove plants. Erratic weather can lead to the death of clove plants and it becomes one of the threat factors that can interfere with the growth of these clove plants.

2) Pests and diseases: One of the threat factors to clove plants in the Teupah Barat Sub-district is pests and diseases. At this time, pests and diseases are one of the threat factors for clove plants that can cause damage or even death to clove plants. In general, pests attacking plants are orchids, shoot destroyers, and leaf destroyers, these pests can cause disrupted plant growth, production decreases even mortality in plants.

Another disease experienced by clove plants in Teupah Barat Sub-district is dead branches, this disease is caused by rotting some of the plant roots which interferes with the uptake of nutrients from the soil. In general, this disease occurs in plants aged 5 years and over that have produced flowers, especially trees growing close to the surface of the water. This disease is very detrimental to farmers because it attacks when the cloves begin to flower.

3) Competitors: To get an increase in yield in clove farming in terms of sales price, one must pay attention to existing competitors. If the cloves from outside Simeulue Island are abundant, the price will usually decrease.

4) Labor: So far, the clearing of clove plantations is still conducted traditionally by employing human labor. It requires expertise and strength in the process of tree logging. Therefore, farmers find it difficult to find labor, sometimes workers are not interested to work due to the work is very draining, so the farmers clear the land themselves the best they could.

5) Price fluctuation: The price of cloves in Simeulue District fluctuates greatly. The exact cause of the drop in clove prices in Simeulue is not yet known. Due to unstable prices, some agents switched to other commodities such as areca nut, cocoa and nutmeg. The price of cloves in 2020 started from 60.000 to $\mathrm{Rp} 70.000$ per $\mathrm{kg}$, down from the previous Rp.80.000 to Rp.120.000 per kilo. Unstable price becomes a threat to the sale of clove plants that can be detrimental to farmers.

\section{E. IFAS Matrix}

TABLE II. IFAS MATRIX FOR ClOVE DEVELOPMENT IN TEUPAH BARAT SUB-DISTRICT

\begin{tabular}{|l|l|l|l|l|}
\hline No & Internal Factors & Weight & Rating & $\begin{array}{c}\text { Weight X } \\
\text { Rating }\end{array}$ \\
\hline \multicolumn{2}{|c|}{ Strengths } & & & \\
\hline 1 & Owned Land & 0,13 & 4 & 0,52 \\
\hline 2 & Land Fertility & 0,12 & 3 & 0,36 \\
\hline 3 & Good Plant Growth & 0,11 & 3 & 0,33 \\
\hline & & & & \\
\hline
\end{tabular}

Table II. Cont.

\begin{tabular}{|c|c|c|c|c|}
\hline No & Internal Factors & Weight & Rating & $\begin{array}{c}\text { Weight X } \\
\text { Rating }\end{array}$ \\
\hline 4 & $\begin{array}{ll}\text { Farming } & \text { Business } \\
\text { Location } & \end{array}$ & 0,09 & 3 & 0,27 \\
\hline 5 & Empty Land & 0,09 & 2 & 0,18 \\
\hline \multicolumn{4}{|c|}{ Sub Total } & 1,66 \\
\hline \multicolumn{2}{|r|}{ Weaknesses } & & & \\
\hline 1 & Lack of Knowledge & 0,11 & 3 & 0,33 \\
\hline 2 & $\begin{array}{l}\text { Lack Attention to the } \\
\text { Plants }\end{array}$ & 0,10 & 3 & 0,30 \\
\hline 3 & Insufficient Funds & 0,10 & 3 & 0,30 \\
\hline 4 & Poor Quality Seeds & 0,08 & 2 & 0,16 \\
\hline 5 & Lack of Fertilizer & 0,07 & 2 & 0,14 \\
\hline \multicolumn{4}{|c|}{ Sub Total } & 1,23 \\
\hline \multicolumn{2}{|c|}{ Total } & 1 & & 0,43 \\
\hline
\end{tabular}

Based on Table 2, it can be seen that the strength factor is more dominant than the weakness with a number of 0,43 . After analysing the internal factors, the external factor analysis is then carried out as follows:

\section{F. EFAS Matrix}

TABLE III. EFAS MATRIX FOR CLOVE DEVELOPMENT IN TEUPAH BARAT SUB-DISTRICT

\begin{tabular}{|c|c|c|c|c|}
\hline No & External Factors & Weight & Rating & $\begin{array}{c}\text { Weight } X \\
\text { Rating }\end{array}$ \\
\hline \multicolumn{5}{|c|}{ Opportunities } \\
\hline 1 & High Price & 0,13 & 4 & 0,52 \\
\hline 2 & Large Number of Buyers & 0,12 & 3 & 0,36 \\
\hline 3 & Product Quality & 0,11 & 3 & 0,33 \\
\hline 4 & $\begin{array}{l}\text { Information and Technology } \\
\text { Development }\end{array}$ & 0,10 & 3 & 0,30 \\
\hline 5 & Product Uniqueness & 0,09 & 2 & 0,18 \\
\hline \multicolumn{4}{|c|}{ Sub Total } & 1,69 \\
\hline \multicolumn{4}{|c|}{ Threats } & \\
\hline 1 & Weather & 0,11 & 3 & 0,33 \\
\hline 2 & Pests and Diseases & 0,09 & 3 & 0,27 \\
\hline 3 & Competitors & 0,09 & 3 & 0,27 \\
\hline 4 & Labor & 0,09 & 3 & 0,27 \\
\hline 5 & Price Fluctuation & 0,07 & 2 & 0,14 \\
\hline \multicolumn{4}{|c|}{ Sub Total } & 1,28 \\
\hline \multicolumn{2}{|c|}{ Total } & 1 & & 0,41 \\
\hline
\end{tabular}

Based on Table 3, it can be seen that the opportunity factor is more dominant than the threat with a number of 0.41 .

\section{G. Determination of Alternative Strategies}

The formulation of alternative clove development strategies in Teupah Barat Sub-district, Simeulue District, is useful for the local government and especially for clove farmers in Teupah Barat Sub-district to be able to use their opportunitiesstrengths and minimize the weaknesses-threats they face. Based on the results of the IFAS and EFAS matrix analysis, the most influential factors in the development of cloves in Teupah Barat Sub-district are strengths and opportunities factors, then an alternative strategy can be formulated for farmers in Teupah 
Barat Sub-district in developing cloves is by using the formulated SO strategy utilising the SWOT matrix as follows:

TABLE IV. DETERMINATION OF THE STRATEGY USED

\begin{tabular}{|c|c|}
\hline IFAS & $\begin{array}{l}\text { STRENGTHS (S) } \\
\text { 1. Owned Land } \\
\text { 2. Land Fertility } \\
\text { 3. Good Plant Growth } \\
\text { 4. Farming Business Location } \\
\text { 5. Empty Land }\end{array}$ \\
\hline $\begin{array}{l}\text { OPPORTUNITIES }(\mathbf{O}) \\
\text { 1. High Price } \\
\text { 2. Large Number of Buyers } \\
\text { 3. Product Quality } \\
\text { 4. Technology and Information } \\
\text { Development } \\
\text { 5. Product Uniqueness }\end{array}$ & $\begin{array}{l}\text { SO STRATEGIES } \\
\text { 1. Expansion of clove development } \\
\text { 2. Replacing damaged plants with } \\
\text { new plants } \\
\text { 3. Selection of quality seeds } \\
\text { 4. Creating clove farmer groups }\end{array}$ \\
\hline
\end{tabular}

Source: Primary Data Processed (2020)

Based on Table 4 the strategy chosen is an SO strategy by relying on strengths to take advantage of opportunities, including:

1) Expansion of clove development: Farmers must continue expanding their clove crop more than before in order to obtain high production yields because the number of clove buyers is very large and very much supported by a large number of vacant land in Teupah Barat Sub-district.

2) Replacing damaged plants with new plants: Farmers have to replace damaged crops with new crops in order to increase higher yields.

3) Selection of quality seeds: Selecting quality clove plant seeds so that the clove yields obtained are of high quality, supported by soil fertility and good plant growth.

4) Creating clove farmer groups: Farmers must create farmer groups to quickly obtain information. The formation of farmer groups can also add insight, skills and experience to them and they can work together in dealing with problems that exist in the clove development process so that the common goal of farmers can be achieved.

\section{CONCLUSION}

The right strategy for developing cloves in Teupah Barat Sub-district, Simeulue District is by using the SO (StrengthOpportunities) strategy, which means creating a strategy by using strength to take advantage of existing opportunities such as: (1) Farmers must continue to expand their clove plants more than before in order to obtain high production yields because the number of clove buyers is very large and in Teupah Barat Sub-district it is very much supported by the large number of vacant land. (2) Farmers must replace damaged plants with new plants in order to increase production yields higher (3) Selection of quality clove plant seeds so that the clove yields obtained are of high quality which is supported by land fertility and good plant growth. (4) Farmers must create farmer groups to quickly obtain information. The formation of farmer groups can also add insight, skills, and experience to them and can work together in dealing with problems that exist in the clove development process so that the common goal of farmers can be achieved. The implementation of the strategies require support from a variety of related parties both government and local community

\section{ACKNOWLEDGMENT}

The publication fund was provided by Teuku Umar University.

\section{REFERENCES}

[1] G. Emet and T.A.T. Merba, "SWOT ANALYSIS: A THEORETICAL REVIEW," The Journal of International Social Research, vol. 10, no. 51, 2017

[2] M. Kajanus, P. Leskinen, M. Kurttila and J. Kangas, "Making use of MCDS methods in SWOT analysis - Lessons learnt in strategic natura resources management," Forest Policy and Economics, vol. 20, pp. 1-9, 2012 .

[3] M.T. Taghavifard, H. Amoozad Mahdiraji, A.M. Alibakhshi, E.K. Zavadskas and R. Bausys, "An extension of fuzzy SWOT analysis: an application to information technology," Information, vol. 9, no. (3), pp. 46, 2018.

[4] M.M. Helms and J. Nixon, "Exploring SWOT analysis-Where are we now? A review of academic research from the last decade," J. Strategy Manag., vol. 3, pp. 215-251, 2010.

[5] R.G. Dyson, "Strategic development and SWOT analysis at the University of Warwick," Eur. J. Oper. Res., vol. 152, pp. 631-640 2004

[6] L. Chang and C. Lin, "The exploratory study of competitive advantage of Hsin-Chu city government by using diamond theory," Bus. Rev, vol 3, pp. 180-185, 2005.

[7] J.K. Khatri and B. Metri, "SWOT-AHP approach for sustainable manufacturing strategy selection: a case of Indian SME," Global Business Review, vol. 17, no. (5), pp. 1211-1226, 2016.

[8] O.C. Farrel and D. Harline, Marketing Strategy. South Western: Thomson Corporation, 2005

[9] K. Miharja, "Analisa SWOT Dalam Menentukan Strategi Bisnis Susu Murni Q-Milk,” Jurnal Ecodemica, vol. 2, no. (1), pp. 30-38, 2018.

[10] R. Elyarni and H. Hermanto, "SWOT Analysis of SAP Express Service Marketing Strategy at PT. SAP,” Jurnal Metris, vol. 17, pp. 81-88, 2016.

[11] D.A. Kurniawan, "Kampoeng Durian Tourism Development Strategy, Ngrogung Village, Ngebel Ponorogo Sub-district through IFAS Matrix Analysis and EFAS,” Al Tijarah, vol. 5, no. 2, pp. 93-103, 2019. 